\title{
Clarithromycin Inhibits Progeny Virus Production from Human Influenza Virus-Infected Host Cells
}

\author{
Daisei Miyamoto, ${ }^{a, b, c}$ Sayaka Hasegawa, ${ }^{a, c}$ Nongluk Sriwilaijaroen, ${ }^{d, e}$ Sangchai YingSaKmongkon, ${ }^{d, f}$ \\ Hiroaki Hiramatsu, ${ }^{b, d}$ Tadanobu TAKahashi, ${ }^{a, b, c}$ Kazuya Hidari ${ }^{a, b, c}$ Chao-Tan Guo, ${ }^{b, d, g}$ \\ Yuichi SAKAno, ${ }^{a, h}$ Takashi SuzUKI, ${ }^{a, b, c}$ and Yasuo SUZUKI ${ }^{*, b, c, d}$
}

${ }^{a}$ Department of Biochemistry, University of Shizuoka School of Pharmaceutical Sciences; ${ }^{b}$ Core Research for Evolutional Science and Technology (CREST, JST), University of Shizuoka School of Pharmaceutical Sciences; ${ }^{c}$ Global COE Program for Innovation in Human Health Sciences, University of Shizuoka School of Pharmaceutical Sciences; 52-1 Yada, Shizuoka, Shizuoka 422-8526, Japan: ${ }^{d}$ Department of Biomedical Sciences, College of Life and Health Sciences, Chubu University; 1200 Matsumoto-cho, Kasugai, Aichi 487-8501, Japan: ${ }^{\circ}$ Graduate Studies, Faculty of Medicine, Thammasat University (Rangsit Campus); Pathumthani 12120, Thailand: ${ }^{f}$ Department of Microbiology and Immunology, Faculty of Veterinary Medicine, Kasetsart University; Bangkok 10900, Thailand: ${ }^{g}$ Zhejiang Academy of Medical Sciences; 182 Tianmushan Road, Hangzhou 310016, China: and ${ }^{h}$ The Japan Health Science Foundation; 13-4 Kodenma-cho, Nihonbashi, Chuo-ku, Tokyo 103-0001, Japan.

Received September 27, 2007; accepted November 15, 2007; published online November 20, 2007

\begin{abstract}
In vitro effects of macrolide clarithromycin (CAM) on influenza A virus-infected cells were examined using plaque reduction assay by treating cells either before or after viral adsorption. The significant inhibitory effect on influenza virus infection was detected only when the cells were treated with CAM after viral adsorption. The predominant inhibitory effect was observed during 4-7th hour after viral adsorption using viral production assay. CAM did not exhibit inhibitory effects on influenza virus hemagglutination, membrane fusion and viral sialidase activities. These findings indicate that CAM acts on a middle to late stage of the viral replication cycle resulting in inhibition of progeny virus production from the infected cells.
\end{abstract}

Key words clarithromycin; influenza virus; anti-influenza drug

Influenza virus infection frequently causes severe acute respiratory infection and is sometimes accompanied by pneumonia, otitis media, meningitis and encephalitis. ${ }^{1-3)}$ Since influenza vaccines have been effective only in reducing prevalence, ${ }^{4,5)}$ anti-influenza agent treatment plays an important role for influenza virus control. Currently, only four antiinfluenza agents which can be divided into two classes are approved for use in treating influenza: i) amantadine and its analogue, rimantadine, act as viral M2 channel blockers, and ii) zanamivir and oseltamivir are viral sialidase inhibitors. ${ }^{6,7}$ Amantadine and rimantadine are active against only influenza A virus, produce rapid drug resistant variants and have central nervous system side effects. ${ }^{8-10)}$ Zanamivir is not indicated for use in children in Japan. ${ }^{11)}$

Clarithromycin (CAM) is a macrolide antibiotic developed by modification of a side chain of 14-atom ring erythromycin via alkylation. ${ }^{12)}$ In addition to being an antibiotic able to prevent complications and aggravation of symptoms, ${ }^{13,14)}$ CAM has been reported to alleviate pneumonia with influenza virus infection in mice. ${ }^{13)}$ Furthermore, CAM has recently been shown to suppress the inflammatory cytokines such as tumor necrosis factor- $\alpha^{15}$ but augment interleukin (IL)-12 production, resulting in alleviation of influenza infection in infected mice. ${ }^{15,16)}$ These studies indicated that CAM may play a role in vivo as an immunomodulator for influenza virus infection.

We here show the ability of CAM in inhibition of human influenza A virus production in vitro at a middle to late stage of viral replication cycle.

\section{MATERIALS AND METHODS}

Compounds Clarithromycin (CAM) ((-)-(3R,4S,5S,-
6R,7R,9R,11R,12R,13S,14R)-4-[2,6-dodeoxy-3-C-methyl-3$O$-methyl- $\alpha$-L-ribo-hexopyranosyl]oxy-14-ethyl-12,13-dihydroxy-7-methoxy-3,5,7,9,11,13-hexamethyl-6-[[3,4,6trideoxy-3-(dimethylamino)- $\beta$-D-xylo-hexopyranosyl]oxy]oxacyclotetradecane-2,10-dione) was obtained from Taisho Toyama Pharmacuetical Co., Ltd. Zanamivir (Relenza; 5acetylamino-2,6-anhydro-4-guanidino-3,4,5-trideoxy-D-glycerol-D-galactonon-2-enoic acid) was obtained from Glaxo Co., Ltd. All compounds were of the highest purity available. CAM was dissolved in methanol and diluted with culture medium for viral infection experiments or with PBS for viral biological experiments to make its various final concentrations. The final concentration of methanol in each culture medium was not more than $0.63 \%$. CAM showed no cytotoxic effect to host MDCK cells up to $50 \mu \mathrm{g} / \mathrm{ml}$ of culture medium, and also no hemolytic activity to the guinea pig erythrocytes up to $100 \mu \mathrm{g} / \mathrm{ml}$ of test medium.

Cells Mardin-Darby canine kidney (MDCK) cells and human lung epithelial A549 cells were maintained in Dulbecco's modified Eagle's medium (DMEM) (SIGMA) supplemented with $10 \%(\mathrm{v} / \mathrm{v})$ fetal bovine serum (FBS) and antibiotics $(100 \mathrm{U} / \mathrm{ml}$ penicillin and $100 \mu \mathrm{g} / \mathrm{ml}$ streptomycin). Human lung epithelial A549 cells were purchased from ATCC.

Viruses The human influenza A viruses used in this study were A/PR/8/34 (H1N1), A/Aichi/2/68 (H3N2), A/Memphis/1/71 (H3N2), and A/WSN/33 (H1N1). Virus strains were propagated in the allantoic cavities of 11-d-old chicken eggs for $48 \mathrm{~h}$ at $35^{\circ} \mathrm{C}$ and purified as described previously. ${ }^{17,18)}$ Viral hemagglutinin (HA) units were determined in microtiter plates using $0.5 \%$ guinea pig erythrocytes.

Plaque Reduction Assay To determine anti-influenza virus activity of agents, plaque reduction assay was per- 
formed using MDCK or A549 cells as described previously. ${ }^{19)}$ Triplicate cultures of cells in 6-well plastic culture dishes were infected with about $30-100 \mathrm{PFU} / 0.8 \mathrm{ml}$ of each virus strains for $1 \mathrm{~h}$ at $34.5^{\circ} \mathrm{C}$. Cells were overlaid with $3 \mathrm{ml}$ of nutrient agarose $(0.8 \%)$ medium containing $1 \mathrm{X}$ ITS solution (GIBCO), $1 \mu \mathrm{g} / \mathrm{ml}$ acetylated trypsin (SIGMA) and various concentrations of CAM and then cultured at $34.5^{\circ} \mathrm{C}$ for 2 or $3 \mathrm{~d}$. The infected cells were fixed with methanol: $\mathrm{CH}_{3} \mathrm{COOH}(\mathrm{v} / \mathrm{v}=5: 1)$ and stained with $0.1 \%$ Amide Black $10 \mathrm{~B}$. The number of plaques was counted under a dissecting microscope. Analysis of significance in difference between plaque numbers in the control and treatment groups was performed by the $t$-test.

Hemagglutinin Inhibition (HAI) Assay Hemagglutinin inhibition (HAI) assay was carried out as described previously. ${ }^{20)}$ Briefly, a virus suspension ( $2^{2}$ of HA units) was incubated for $1 \mathrm{~h}$ at $4{ }^{\circ} \mathrm{C}$ with agents serially diluted two-fold with $0.01 \%$ gelatin-containing phosphate-buffered saline (PBS) in 96-well microtiter plates. After adding 0.5\% (v/v) of guinea pig erythrocytes to each well, the plates were kept for $1 \mathrm{~h}$ at $4{ }^{\circ} \mathrm{C}$. The maximum dilution of the agents showing complete inhibition of hemagglutination was defined as the titer of hemagglutinin inhibition.

Sialidase Inhibition Assay Fetuin was used as a substrate of influenza virus sialidases. A virus suspension $\left(2^{8}\right.$ of HA units) was preincubated for $1 \mathrm{~h}$ at $4{ }^{\circ} \mathrm{C}$ with various dilutions of each agent. The treated virus mixture was added to $0.5 \mathrm{~mm}$ substrate and then incubated for $30 \mathrm{~min}$ at $37^{\circ} \mathrm{C}$. After the incubation, the reaction was terminated by the addition of $500 \mathrm{~mm}$ carbonate buffer ( $\mathrm{pH} \mathrm{10.7).} \mathrm{The} \mathrm{amount} \mathrm{of}$ sialic acid released was determined by the thiobarbituric acid method according to Aminoff method. ${ }^{21,22)}$ The inhibitory effect of each agent was analyzed by plotting the amount of sialic acid released per minute versus concentration of the agent.

Hemolysis Inhibition Assay The hemolysis inhibition assay was carried out as described previously. ${ }^{20,23)}$ Briefly, influenza viruses $\left(2^{8} \mathrm{HAU}\right)$ were preincubated for $1 \mathrm{~h}$ at $4{ }^{\circ} \mathrm{C}$ with various concentration of each agent in $50 \mu \mathrm{l}$ of PBS. The mixtures were then reacted for $30 \mathrm{~min}$ at $4{ }^{\circ} \mathrm{C}$ with $0.5 \mathrm{ml}$ of PBS containing $2.5 \%(\mathrm{v} / \mathrm{v})$ of guinea pig erythrocytes. Erythrocytes were sedimented and resuspended in $0.5 \mathrm{ml}$ of $20 \mathrm{~mm}$ acetate-buffered saline ( $\mathrm{pH} 5.0$ ) for hemolysis mediated by each virus. The hemolysis was carried out for $30 \mathrm{~min}$ at $37^{\circ} \mathrm{C}$ and terminated by addition of an equal volume of PBS. The mixtures were centrifuged, and the concentrations of hemoglobin in the supernatants were determined by measuring the absorbance at $540 \mathrm{~nm}$. To achieve complete hemolysis, Triton X-100 solution was added to the erythrocyte suspension instead of the virus-reagent mixture with a final concentration of $0.1 \%(\mathrm{v} / \mathrm{v})$. The percent hemolysis of each agent was calculated by comparing its absorbance with the absorbance of $0.1 \%$ Triton X-100, taken as $100 \%$ hemolysis.

Viral Production Assay Viral production assay was performed as previously described by Hidari K.I.P.J. et al. ${ }^{23)}$ with minor modification. MDCK cells $\left(0.8 \times 10^{5}\right.$ cells $/$ well $)$ or A549 cells $\left(2.0 \times 10^{5}\right.$ cells/well $)$ were seeded in 12 -well plates and cultured in DMEM supplemented with $10 \%(\mathrm{v} / \mathrm{v})$ FBS at $37^{\circ} \mathrm{C}$ for $24 \mathrm{~h}$. After three washes in serum-free (SF)DMEM, the cells were inoculated for $1 \mathrm{~h}$ at $34.5^{\circ} \mathrm{C}$ with multiple infection or single hit infection. For multiple infection, the cells were infected at a low multiplicity of infection (MOI) of 0.00025 , and the infected cells were incubated with the agent for 25 or $45 \mathrm{~h}$ in SF-DMEM containing 1X ITS solution and $1 \mu \mathrm{g} / \mathrm{ml}$ acetylated trypsin. For single hit infection, the cells were infected at a high MOI of $0.5-1$, and the infected cells were incubated with the agent for 12 or $18 \mathrm{~h}$ in SF-DMEM containing 1X ITS solution without acetylated trypsin. After incubation, the culture medium was collected and the amount of progeny virus produced in the medium was estimated by the plaque assay. For investigation when the agent has an inhibitory effect on progeny virus production, the assay was performed as shown in Fig. 3.

\section{RESULTS}

In Vitro Anti-influenza Virus Activity We examined anti-influenza virus activity of CAM against A/PR/8/34 (H1N1) and A/Aichi/2/68 (H3N2) strains by plaque reduction assay. When CAM was added to the nutrient agarose medium after virus adsorption to host MDCK cells, the numbers of virus plaques were significantly reduced at 12.5 $\mu \mathrm{g} / \mathrm{ml} \mathrm{CAM}$ and were obviously reduced at $25 \mu \mathrm{g} / \mathrm{ml} \mathrm{CAM}$, indicating that CAM inhibits virus production in a dose-dependent manner (Figs. 1a,b). The size of plaques under this condition appeared to be slightly affected by the treatment with CAM. On the other hand, when we examined the effect of CAM on the attachment of virus to cells after pretreatment of the viruses with CAM, there was no or little significant difference between the effects with and without pretreatment. These results suggest that CAM exerts an anti-influenza effect on progeny virus production after viral adsorption to host cells.

Effects of CAM on the Biological Activities of Influenza A Viruses To investigate whether the effects of CAM on plaque reduction are due directly to biological activities of influenza A viruses, we carried out hemagglutination inhibition, viral sialidase activity inhibition and hemolysis inhibition assays. First, we examined the effect of CAM on virusmediated hemagglutination. Erythrocyte hemagglutination is mediated by the interaction of viral hemagglutinin and sialic acid containing glycoconjugates on the surfaces of erythrocytes. ${ }^{17,18,24-26)}$ Following incubation of erythrocytes with influenza A viruses, A/PR/8/34 (H1N1) and A/Aichi/2/68 (H3N2), pretreated with $5-100 \mu \mathrm{g} / \mathrm{ml}$ of CAM, no inhibition of virus-mediated hemagglutination was observed (Fig. 2a). As a control, fetuin-treated viruses, however, demonstrated a significant reduction in erythrocyte hemagglutination. These results suggest that CAM does not interfere with the viral attachment to host cell surfaces. Next, we determined the inhibitory effect of CAM on virus-mediated membrane fusion by hemolysis inhibition assay: the viruses tested in this study were $\mathrm{A} / \mathrm{PR} / 8 / 34$ (H1N1), A/Aichi/2/68 (H3N2), A/Memphis/1/71 (H3N2) and A/WSN/33 (H1N1). Viral HA is proteolytically cleaved into HA1 and HA2 subunits; under acidic conditions, the cleaved HA2 subunit mediates membrane fusion between host cells and viruses. ${ }^{26,27)}$ Figure $2 \mathrm{~b}$ shows that 1 to $100 \mu \mathrm{g} / \mathrm{ml} \mathrm{CAM}$ inhibited influenza-mediated hemolysis at most by $2-3 \%$ of control levels, indicating that the virus-mediated hemolysis was not affected by CAM. These results suggest that anti-influenza activity of 
a)

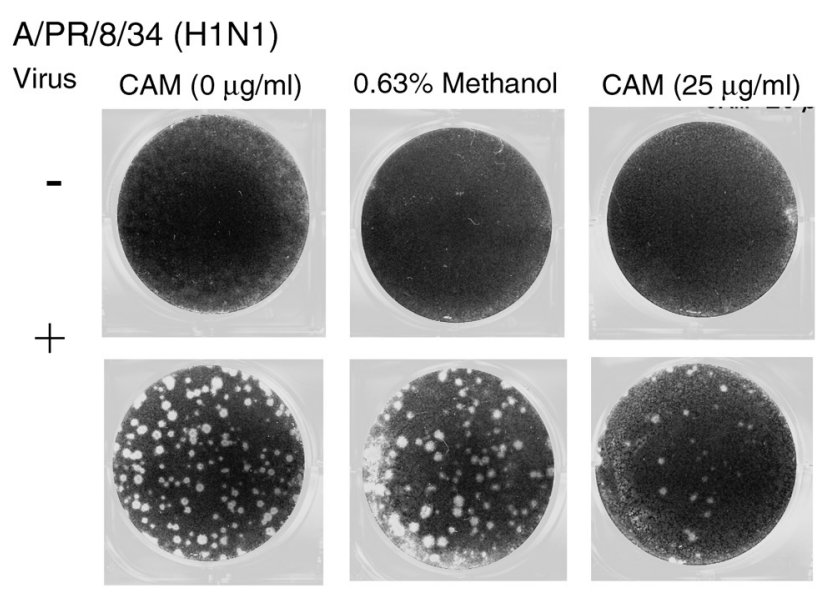

CAM $(0 \mu \mathrm{g} / \mathrm{ml}) \quad$ CAM $(12.5 \mu \mathrm{g} / \mathrm{ml}) \quad$ CAM $(25 \mu \mathrm{g} / \mathrm{ml})$

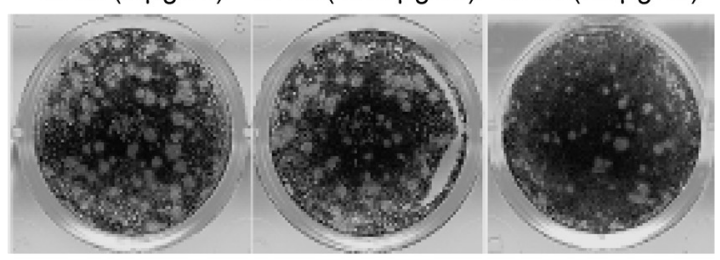

b)

$\mathrm{A} / \mathrm{PR} / 8 / 34(\mathrm{H} 1 \mathrm{~N} 1)$

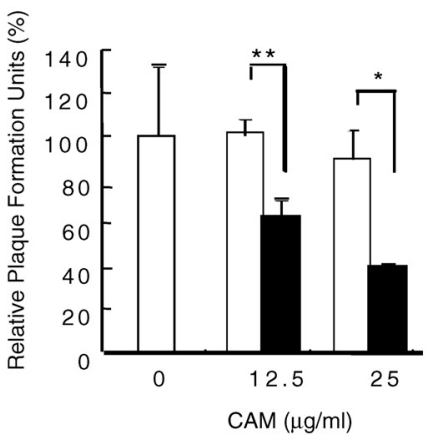

A/Aichi/2/68 (H3N2)

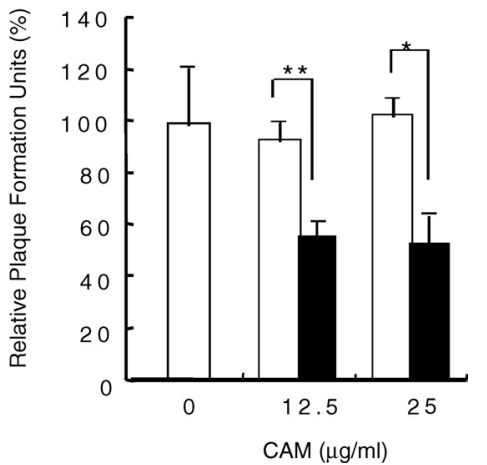

Fig. 1. CAM Inhibits Plaque Formation by Infection of Influenza A Viruses

Plaque reduction assays were performed as described in Materials and Methods. For treatment of cells after viral adsorption, the cells were inoculated with the virus for $1 \mathrm{~h}$. Following washing, the cells were treated with the agent at indicated concentrations or not treated. Panel A (upper left) shows plaques on plates treated or not treated with $25 \mu \mathrm{g} / \mathrm{ml}$ CAM and $0.63 \%(\mathrm{v} / \mathrm{v})$ methanol as a solvent control. Panel A (lower left) shows plaques on plates treated with CAM at the indicated concentrations $(0,12.5,25 \mu \mathrm{g} / \mathrm{ml})$. The figures show representative results of three independent experiments. Graph B (right) showed that summary of the number of plaques on plates treated with CAM at the indicated concentrations. The graph shows one representative result of three independent experiments. Values are means of relative ratios of viral infection in treated cells to that in untreated cells. Bars indicate standard deviations. Closed square, CAM $(0,12.5,25 \mu \mathrm{g} / \mathrm{ml})$ treatment of cells after viral adsorption; Open square, methanol $(\mathrm{v} / \mathrm{v})(0,0.32,0.63 \%)$ treatment of cells after viral adsorption. Significant differences from viral infection without agents are indicated by $* p<0.01, * * p<0.05$.

CAM does not seem to occur at a membrane fusion stage in infection. Further, to clarify the mechanism by which CAM inhibits viral infection, we investigated its effect on viral sialidase activity. Viral silidase activity is necessary for proper budding of virus particles. ${ }^{28-30)}$ As shown in Fig. 2c, CAM had little inhibitory effect on the sialidase activity of $\mathrm{A} / \mathrm{PR} / 8 / 34$ (H1N1), A/Aichi/2/68 (H3N2) and A/Memphis/1/71 (H3N2) at concentrations of more than $50 \mu \mathrm{g} / \mathrm{ml}$ when compared to the methanol solvent control. Zanamivir, as a positive control, showed a strong inhibitory effect on viral sialidase activity as previously reported. ${ }^{30)}$ Fifty percent inhibitory concentrations $\left(\mathrm{IC}_{50}\right)$ of zanamivir against $\mathrm{A} / \mathrm{PR} /$ 8/34 (H1N1), A/Aichi/2/68 (H3N2) and A/Memphis/1/71 (H3N2), were $2.5,5$ and $10 \mathrm{~nm}$, respectively. Overall, these results indicate that CAM does not affect biological activities of influenza A viruses including hemagglutination, membrane fusion and viral sialidase activities.

Effects of CAM on the Production of Progeny Viruses from Influenza A Virus-infected Host Cells The results described above suggest that reduction of virus plaque numbers is not due to prevention of viral biological activities. To clarify the inhibition of virus production from host cells, we examined the amounts of viruses produced from infected host cells in the presence of CAM compared to that in the absence of CAM. Under a multiple infection assay condition, the amounts of viruses produced from MDCK cells infected at low MOI was decreased about $20-80 \%$ depending on virus strain after 25 or $45 \mathrm{~h}$ post infection with $25 \mu \mathrm{g} / \mathrm{ml}$ CAM (Table 1). Under the single hit infection assay condition, the amounts of viruses produced from MDCK cells infected at high MOI was decreased almost $100 \%$ after $12 \mathrm{~h}$ post infection with $25 \mu \mathrm{g} / \mathrm{ml}$ CAM (Table $2 \mathrm{a}$ ). In addition to determination of virus production, under the single hit infection assay condition, apoptotic cell numbers of virus-infected cells after $24 \mathrm{~h}$ post infection with $25 \mu \mathrm{g} / \mathrm{ml} \mathrm{CAM}$ was determined by flow cytometric analysis as described previously. ${ }^{31)}$ Apoptotic cell numbers of virus-infected cells, which were calculated as the percentage of apoptotic to total cells, were decreased to $2-4 \%$ from $40-50 \%$, indicating that CAM inhibits virus-induced apoptosis (data not shown). The same results were obtained by the viral production assay using A549 cells instead of MDCK cells (Table 2b). These data suggest that CAM might exert an anti-influenza effect via inhibition of viral replication in infected host cells, resulting in reduction of progeny virus production and delay of virusinduced apoptosis. Therefore, we determined the incubation times of CAM needed to reduce virus production from infected A549 cells. As shown in Fig. 3, under the single hit infection condition, an inhibitory effect of CAM on virus production was observed when the agent was excluded from the medium at 7 , not 1 or $4 \mathrm{~h}$ post infection. This result was similar to when CAM was not excluded from the medium after 
a)

Fetuin $(\mathrm{mg} / \mathrm{ml})$

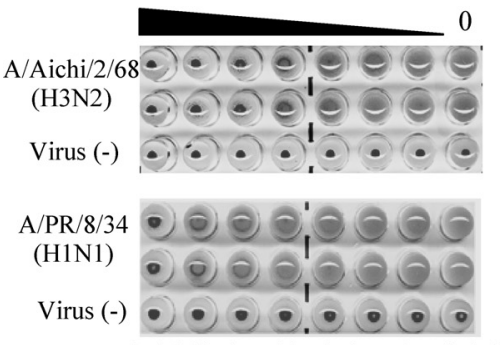

Serial dilution of fetuin from $1 \mathrm{mg} / \mathrm{ml}$
$\operatorname{CAM}(\mu \mathrm{g} / \mathrm{ml})$

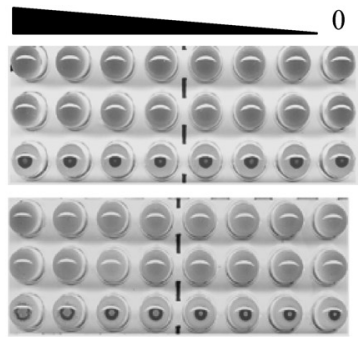

Methanol (\%)

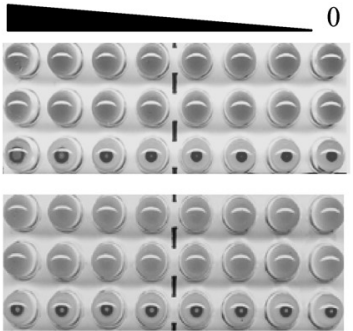

b)

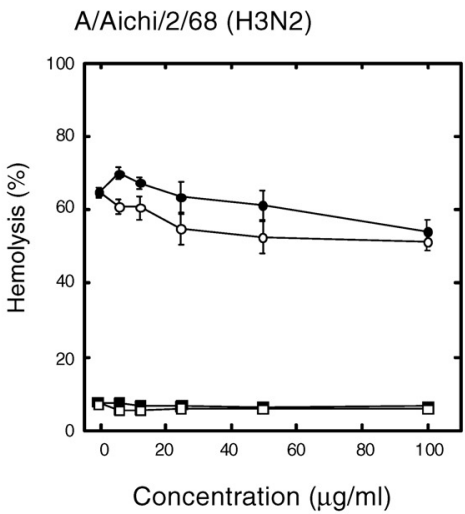

c)

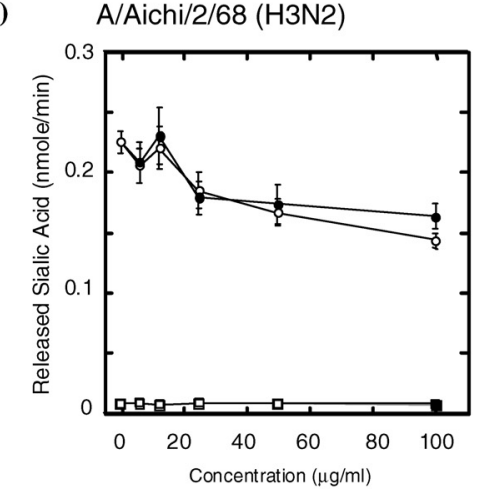

$\mathrm{A} / \mathrm{PR} / 8 / 34(\mathrm{H} 1 \mathrm{~N} 1)$

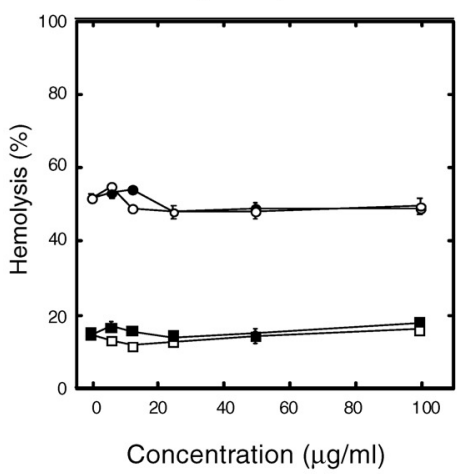

$\mathrm{A} / \mathrm{PR} / 8 / 34(\mathrm{H} 1 \mathrm{~N} 1)$

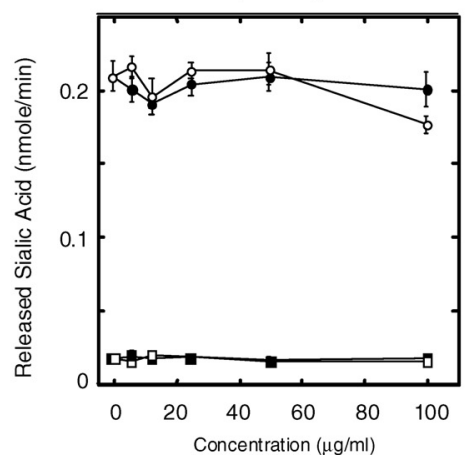

Fig. 2. Effects of CAM on Hemagglutination, Hemolysis and Sialidase Activities with Influenza A Viruses

a) After serial dilution of $1 \mathrm{mg} / \mathrm{ml}$ fetuin, $100 \mu \mathrm{g} / \mathrm{ml} \mathrm{CAM}$ and $0.5 \%(\mathrm{v} / \mathrm{v})$ methanol with PBS, the assay was carried out as described in Materials and Methods. The figure shows representative results of three independent experiments. b) Hemolysis of erythrocytes with influenza viruses was carried out in triplicate as described in Materials and Methods. Open circles, CAM $(0-100 \mu \mathrm{g} / \mathrm{ml})$ treatment with virus; closed circles, methanol $(\mathrm{v} / \mathrm{v})(0-5 \%)$ treatment with virus; open squares, CAM $(0-100 \mu \mathrm{g} / \mathrm{ml})$ treatment without virus; closed squares, methanol (v/v) $(0-5 \%)$ treatment without virus. c) Virus sialidase assay was carried out in triplicate as described in Materials and Methods. Open circles, CAM $(0-100 \mu \mathrm{g} / \mathrm{ml})$ treatment with virus; closed circles, methanol $(\mathrm{v} / \mathrm{v})(0-5 \%)$ treatment with virus; open squares, CAM $(0-100 \mu \mathrm{g} / \mathrm{ml})$ treatment without virus; closed squares, methanol $(\mathrm{v} / \mathrm{v})(0-5 \%)$ treatment without virus.

Table 1. Progeny Virus Production from MDCK Cells Infected with Human Influenza Viruses at Low MOI in the Presence or Absence of Inhibitors

\begin{tabular}{|c|c|c|c|c|}
\hline Incubation (h) & Agent & $\mathrm{A} / \mathrm{PR} / 8 / 34$ & $\mathrm{~A} /$ Aichi/2/68 & $\mathrm{A} /$ Aichi/2/68 \\
\hline \multirow{4}{*}{25} & & $\mathrm{pfu} / \mathrm{ml}\left(\times 10^{3}\right)$ & $\mathrm{pfu} / \mathrm{ml}\left(\times 10^{4}\right)$ & $\mathrm{pfu} / \mathrm{ml}$ \\
\hline & - & $0.66 \pm 0.06(100)$ & $4.20 \pm 0.26(100)$ & N.D. \\
\hline & Methanol & $0.51 \pm 0.07 *(77)$ & $3.57 \pm 0.25 *(85)$ & N.D. \\
\hline & CAM & $0.28 \pm 0.03 * *$ & $2.20 \pm 0.17 * *(52)$ & N.D. \\
\hline \multirow{4}{*}{45} & & $\mathrm{pfu} / \mathrm{ml}\left(\times 10^{5}\right)$ & $\mathrm{pfu} / \mathrm{ml}\left(\times 10^{6}\right)$ & $\mathrm{pfu} / \mathrm{ml}\left(\times 10^{4}\right)$ \\
\hline & - & $1.93 \pm 0.11(100)$ & $1.44 \pm 0.036(100)$ & $3.30 \pm 0.35(100)$ \\
\hline & Methanol & $1.38 \pm 0.23 *(72)$ & $1.40 \pm 0.093(97)$ & $3.20 \pm 0.40(97)$ \\
\hline & CAM & $0.33 \pm 0.08 * * *(17)$ & $1.14 \pm 0.032 * * *(79)$ & $2.27 \pm 0.21 *(69)$ \\
\hline
\end{tabular}

The virus numbers in the supernatants of virus-infected cells were determined in duplicate by the plaque formation assay as described in Materials and Methods. The values are means and standard deviations of the virus numbers in the supernatant of virus-infected cells at the indicated times in the presence or absence of the agents. The values in parenthesis are the percentage of control. Significant differences from viral infection without agents are indicated by $* p<0.05, * * p<0.01, * * * p<0.005$. N.D.: not detected. 
a)

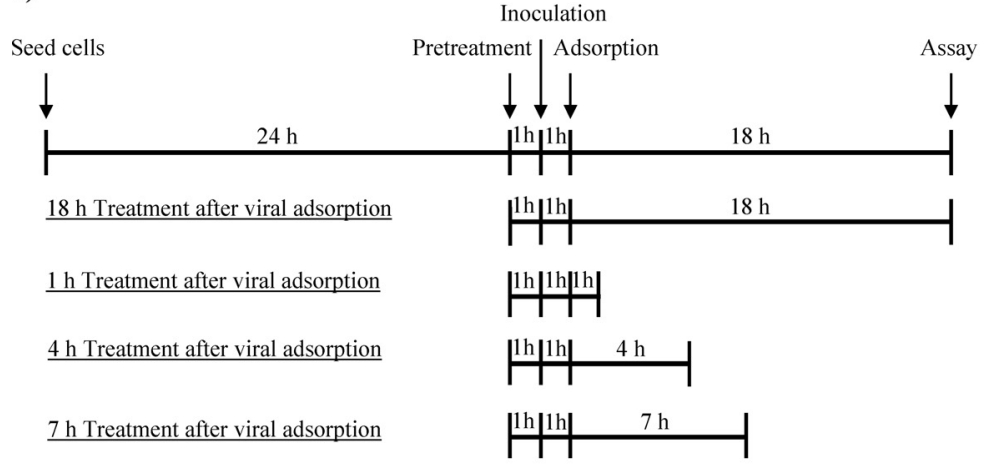

b)
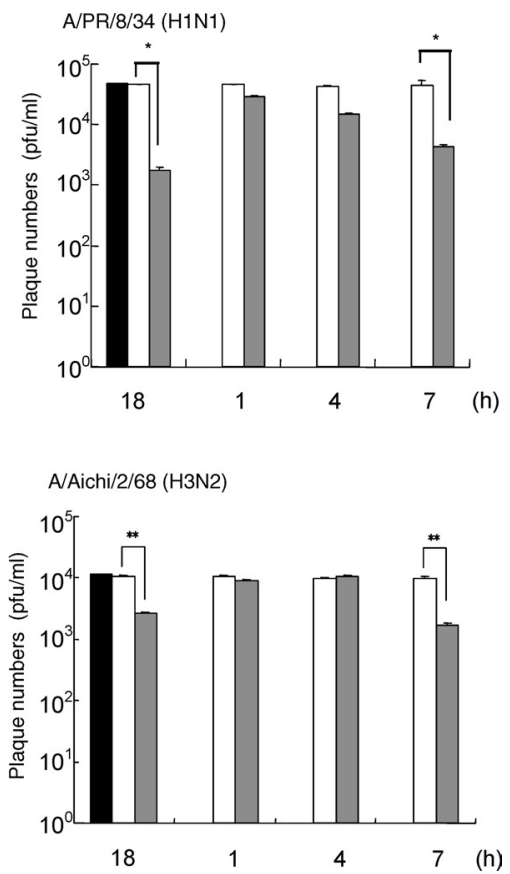

Fig. 3. CAM Inhibits Progeny Virus Production from A549 Cells Infected with Influenza A Viruses

a) The figure shows a diagram of viral production assay. b) After pretreatment of cells for $1 \mathrm{~h}$ in the presence or absence of CAM (25 $\mu \mathrm{g} / \mathrm{ml})$, the cells were inoculated with the virus at MOI of $0.5-1$ for $1 \mathrm{~h}$ in the presence or absence of CAM. Following washing, cells were further incubated with or without the agent for the indicated times. After incubation, the cells were washed twice and then cultured until 18 h in SF-DMEM containing 1X ITS solution. After the culture, the supernatants were collected and the virus numbers were determined by the plaque formation assay as described in Materials and Methods. The figure shows representative results of three independent experiments. Values are means of virus numbers produced from the infected cells. Bars indicate standard deviations. Closed bars, medium alone; open bars, methanol (v/v) $(0.63 \%)$ treatment of cells; dotted bars, CAM $(25 \mu \mathrm{g} / \mathrm{ml})$ treatment of cells. Significant differences from viral infection with methanol are indicated by $* p<0.01, * * p<0.05$.

Table 2. Progeny Virus Production from A549 and MDCK Cells Infected with Human Influenza Viruses at High MOI in the Presence or Absence of Inhibitors

a) MDCK cells

\begin{tabular}{cllc}
\hline \hline Incubation (h) & Agent & \multicolumn{1}{c}{$\mathrm{A} / \mathrm{PR} / 8 / 34$} & $\mathrm{~A} / \mathrm{Aichi} / 2 / 68$ \\
\hline & & $\mathrm{pfu} / \mathrm{ml}\left(\times 10^{3}\right)$ & $\mathrm{pfu} / \mathrm{ml}\left(\times 10^{3}\right)$ \\
12 & - & $8.50 \pm 0.02(100)$ & $10.00 \pm 0.15(100)$ \\
& Methanol & $8.30 \pm 0.10(98)$ & $9.10 \pm 0.02(91)$ \\
& CAM & $0.12 \pm 0.02 *(1.4)$ & $1.00 \pm 0.10^{*}(10)$ \\
\hline
\end{tabular}

b) A549 cells

\begin{tabular}{cccl}
\hline \hline Incubation (h) & Agent & $\mathrm{A} / \mathrm{PR} / 8 / 34$ & $\mathrm{~A} / \mathrm{Aichi} / 2 / 68$ \\
& & $\mathrm{pfu} / \mathrm{ml}\left(\times 10^{3}\right)$ & $\mathrm{pfu} / \mathrm{ml}\left(\times 10^{3}\right)$ \\
\multirow{3}{*}{18} & - & $21.10 \pm 0.22(100)$ & $5.00 \pm 0.01(100)$ \\
& Methanol & $19.80 \pm 0.05(94)$ & $4.80 \pm 0.05(96)$ \\
& CAM & $1.00 \pm 0.02 *(4.7)$ & $1.00 \pm 0.10^{* *}(20)$
\end{tabular}

The virus numbers in the supernatants of virus-infected cells were determined in duplicate by the plaque formation assay as described in Materials and Methods. The values are means and standard deviations of the virus numbers in the supernatant of virusinfected cells at the indicated times in the presence or absence of the agents. Significant differences from viral infection without agents are indicated by $* p<0.05, * * p<0.01$

addition. Produced viruses in the excluded medium were not detected at least under our assay conditions (data not shown). This result indicates that CAM might exert an anti-influenza virus effect during $4-7$ th hour after virus infection.

\section{DISCUSSION}

CAM administration in vivo augments IL-12 level in the airway, resulting in alleviation of influenza virus infec- tion. ${ }^{15,16)}$ In our experiments, pretreatment of cells with CAM had little effect on the influenza infectivity of MDCK cells and A549 cells (data not shown). On the other hand, posttreatment with CAM at a final concentration of $25 \mu \mathrm{g} / \mathrm{ml}$ had a strong inhibitory effect on plaque reduction of the tested human influenza A viruses. This observation was in agreement with the results under a multiple infection assay and a single hit infection assay conditions, indicating that progeny virus production from infected host cells, either MDCK or A549 cells, was significantly decreased at $25 \mu \mathrm{g} / \mathrm{ml}$ CAM. In addition to decrease of progeny virus production, CAM decreased apoptotic cell numbers of infected host cells. A similar observation has been reported for amantadine and thujaplicin copper chelates having anti-influenza activity. ${ }^{32,33)}$ These findings suggest that CAM acts directly on virusinfected cells and contributes to the prevention of virus production by inhibiting viral replication in infected host cells.

The influenza-virus replication cycle can be divided into 5 steps: i) binding of viral hemagglutinin to sialic acid receptor on host cell surface (adsorption step), ii) internalization of virus by receptor-mediated endocytosis and fusion of viral HA2 with endosomal membranes triggered by influx of protons through M2 channel (endocytosis and fusion step), iii) release of viral genes into the cytoplasm (uncoating step), iv) packaging of viral proteins with viral genes after viral RNA replication, transcription and translation, and budding of new viruses (packaging and budding step), v) release of new viruses by sialidase cleaving sialic acid receptors (release step) ${ }^{6,7)}$ However, CAM had no or little inhibitory effect on hemagglutination, hemolysis activity (membrane fusion) and sialidase activity, These results suggest that decrease of progeny virus production is not due to inhibition of viral hemag- 
glutinin and sialidase activities, which play an important role at the beginning and the end of viral replication, respectively. After CAM was incubated with virus-infected cells at different times, we found that CAM predominantly inhibited viral replication after viral adsorption to host cells at about $4-7$ th hour. One-step growth in MDCK or A549 cell of influenza A virus with high MOI is completed after $10-12 \mathrm{~h}$ of virus inoculation (data not shown). Together, the data suggest that CAM might act on a middle to late stage of viral replication cycle, presumably via blockage of producing viral protein. CAM has previously been found to be an immunomodulator when administered in bacterial-infected animal model ${ }^{34,35)}$ but the direct anti-bacterial effect of CAM has been attributed to inhibition of bacterial protein synthesis. ${ }^{36,37)}$

In conclusion, this study has demonstrated that CAM inhibits influenza-virus production in vitro. A significant inhibitory effect of CAM on influenza-virus infection in an in vivo animal model study has previously been reported. ${ }^{16)}$ These findings strongly encourage the potential use of CAM as an anti-influenza virus chemotherapeutic agent.

Acknowledgements This work was supported by CREST (Japan Science and Technology Agency). A part of this work was also supported by Mitsubishi Foundation, Heiwa Nakajima Foundation, The Tokyo Biochemical Research Foundation, and Toukai Foundation for Technology.

\section{REFERENCES}

1) Akaike T., Ando M., Oda T., Doi T., Ijiri S., Araki S., Maeda H., J. Clin. Invest., 85, 739-745 (1990).

2) Siberry G. K., Pediatr. Ann., 29, 683-690 (2000).

3) Aiba H., Hamazaki Y., Oguro K., Hojo H., J. Jpn. Pediatr. Soc., 104, $451-454$ (2000).

4) Reichert T. A., Sugaya N., Fedson D. S., Glezen W. P., Simonsen L., Tashiro M., N. Engl. J. Med., 344, 889-896 (2001).

5) Sugaya N., Nerome K., Ishida M., Matsumoto M., Mitamura K., Nirasawa M., JAMA, 272, 1122-1126 (1994).

6) Palese P., Nat. Med., 10, S82-S87 (2004).

7) De Clercq E., Nat. Rev. Drug Discov., 5, 1015-1025 (2006).

8) Hall C. B., Dolin R., Gala C. L., Markovitz D. M., Zhang Y. Q., Madore P. H., Disney F. A., Talpey W. B., Green J. L., Francis A. B., Pichichero M. E., Pediatrics, 80, 275-282 (1987).

9) Atkinson W. L., Arden N. H., Patriarca P. A., Leslie N., Lui K. J., Gohd R., Arch. Intern. Med., 146, 1751-1756 (1986).

10) Nicholson K. G., Wood J. M., Zambon M., Lancet, 362, 1733-1745 (2003).

11) Matsumoto K., Ogawa N., Nerome K., Numazaki Y., Kawakami Y., Shirato K., Arakawa M., Kudoh S., Shimokata K., Nakajima S., Yamakido M., Kashiwagi S., Nagatake T., Antivir. Ther., 4, 61-68 (1999).

12) Hashisaki G. T., Am. J. Otolaryngol., 16, 153-157 (1995).
13) Sato K., Suga M., Akaike T., Fujii S., Muranaka H., Doi T., Maeda H., Ando M., Am. J. Respir. Crit. Care Med., 157, 853-857 (1998).

14) Maeda S., Yamada Y., Nakamura H., Maeda T., Pediatr. Int., 41, 274 276 (1999).

15) Kido H., Okumura Y., Yamada H., Le T. Q., Yano M., Curr. Pharm. Des., 13, 403-412 (2007).

16) Tsurita M., Kurokawa M., Imakita M., Fukuda Y., Watanabe Y., Shiraki K., J. Pharmacol. Exp. Ther., 298, 362-368 (2001).

17) Suzuki Y., Matsunaga M., Matsumoto M., J. Biol. Chem., 260, 13621365 (1985).

18) Suzuki Y., Nagao Y., Kato H., Matsumoto M., Nerome K., Nakajima K., Nobusawa E., J. Biol. Chem., 261, 17057-17061 (1986).

19) Watanabe W., Sudo K., Asawa S., Konno K., Yokota T., Shigeta S., J. Virol. Methods, 51, 185-191 (1995).

20) Suzuki Y., Suzuki T., Matsumoto M., J. Biochem. (Tokyo), 93, 16211633 (1983).

21) Aminoff D., Biochem. J., 81, 384-392 (1961).

22) Guo C. T., Sun X. L., Kanie O., Shortridge K. F., Suzuki T., Miyamoto D., Hidari K. I. P. J., Wong C. H., Suzuki Y., Glycobiology, 12, 183190 (2002).

23) Hidari K. I. P. J., Tsujii E., Hiroi J., Mano E., Miyatake A., Miyamoto D., Suzuki T., Suzuki Y., Biol. Pharm. Bull., 27, 825-830 (2004).

24) Suzuki Y., Kato H., Naeve C. W., Webster R. G., J. Virol., 63, 42984302 (1989).

25) Suzuki Y., Nakao T., Ito T., Watanabe N., Toda Y., Xu G., Suzuki T., Kobayashi T., Kimura Y., Yamada A., Sugawara K., Nishimura H., Kitame F., Nakamura K., Deya E., Kiso M., Hasagawa A., Virology, 189, 121-131 (1992).

26) Weis W., Brown J. H., Cusack S., Paulson J. C., Skehel J. J., Wiley D. C., Nature (London), 333, 426-431 (1988).

27) White J. M., Science, 258, 917-924 (1992).

28) Liu C., Eichelberger M. C., Compans R. W., Air G. M., J. Virol., 69, 1099-1106 (1995).

29) Sidwell R. W., Huffman J. H., Barnard D. L., Bailey K. W., Wong M. H., Morrison A., Syndergaard T., Kim C. U., Antiviral. Res., 37, 107120 (1998)

30) von Itzstein M., Wu W. Y., Kok G. B., Pegg M. S., Dyason J. C., Jin B., Van Phan T., Smythe M. L., White H. F., Oliver S. W., Colman P. M., Varghese J. N., Ryan D. M., Woods J. M., Bethell R. C., Hotham V. J., Cameron J. M., Penn C. R., Nature (London), 363, 418- 423 (1993).

31) Miyamoto D., Ueno T., Takashima S., Ohta K., Miyawaki T., Suzuki T., Suzuki Y., Glycoconj. J., 14, 379-388 (1997).

32) Morris S. J., Price G. E., Barnett J. M., Hiscox S. A., Smith H., Sweet C., J. Gen. Virol., 80, 137-146 (1999).

33) Miyamoto D., Kusagaya Y., Endo N., Sometani A., Takeo S., Suzuki T., Arima Y., Nakajima K., Suzuki Y., Antiviral. Res., 39, 89-100 (1998).

34) Giamarellos-Bourboulis E. J., Antonopoulou A., Raftogiannis M., Koutoukas P., Tsaganos T., Tziortzioti V., Panagou C., Adamis T., Giamarellou H., BMC Infect. Dis., 6, 31 (2006).

35) Giamarellos-Bourboulis E. J., Tziortzioti V., Koutoukas P., Baziaka F., Raftogiannis M., Antonopoulou A., Adamis T., Sabracos L., Giamarellou H., J. Antimicrob. Chemother, 57, 937-944 (2006).

36) Dinos G. P., Connell S. R., Nierhaus K. H., Kalpaxis D. L., Mol. Pharmacol., 63, 617-623 (2003).

37) Sherman D., Xiong L., Mankin A. S., Melman A., Bioorg. Med. Chem. Lett., 16, 1506-1509 (2006). 